\title{
PERAN CUSTOMER SATISFACTION MEMEDIASI PENGARUH PERCEIVED EASE OF USE DAN PERCEIVED ENJOYMENT TERHADAP REPURCHASE INTENTION
}

\author{
Made Ayu Swari Oktarini ${ }^{1}$ \\ I Made Wardana ${ }^{2}$ \\ ${ }^{1,2}$ Fakultas Ekonomi dan Bisnis Universitas Udayana, Bali, Indonesia \\ e-mail: ayuswari20@yahoo.com
}

\begin{abstract}
ABSTRAK
Penelitian ini dilakukan pada pengguna jasa Traveloka di Kota Denpasar dengan jumlah sampel sebanyak 120 sampel. Pengumpulan data dilakukan dengan menyebarkan kuesioner. Selanjutnya, data dari hasil pengumpulan kuesioner diuji validitas dan uji reliabilitas untuk mengetahui kelayakan dan konsistensi indikator dalam kuesioner. Selain itu, dilakukan uji lain menggunakan Confirmatory Factor Analysis (CFA), analisis jalur dan uji Sobel. Ditemukan bahwa variabel perceived ease of use dan perceived enjoyment masing-masing berpengaruh positif dan signifikan terhadap customer satisfaction konsumen Traveloka di Kota Denpasar. Variabel perceived ease of use, perceived enjoyment dan customer satisfaction berpengaruh positif dan signifikan terhadap repurchase intention. Penelitian membuktikan bahwa customer satisfaction secara signifikan memediasi pengaruh perceived ease of use dan perceived enjoyment terhadap repurchase intention pada situs Traveloka di Kota Denpasar.
\end{abstract}

Kata kunci: perceived ease of use, perceived enjoyment, customer satisfaction, repurchase intention.

\begin{abstract}
This study was conducted on the Traveloka user on Denpasar City with 120 total of samples. Data collection with questionnaire. The data result from questionnaire tested for validity and reliability. Furthermore, another data analyzed using Confirmatory Factor Analysis (CFA), path analysis and Sobel test. This research show that perceived ease of use and perceived enjoyment have positive and significant impact on customer satisfaction. Perceived ease of use, perceived enjoyment and customer satisfaction have positive and significant impact on repurchase intention.This research show that customer satisfaction significantly mediating perceived ease of use and perceived enjoyment toward repurchase intention on Traveloka website in Denpasar City.
\end{abstract}

Keyword: perceived ease of use, perceived enjoyment, customer satisfaction, repurchase intention. 


\section{PENDAHULUAN}

Internet merupakan salah satu implementasi kemajuan teknologi yang saat ini terus dikembangkan diseluruh dunia. Penyebaran akses internet yang semakin luas menjadikan internet sebagai kebutuhan yang tidak terlepas dari kehidupan seharihari. Internet juga membawa perubahan besar dalam perkembangan bisnis di seluruh dunia. Ketersediaan internet memberikan kesempatan pada pelaku bisnis untuk meningkatkan pemasaran produk atau jasa secara global. Penggunaan internet dalam melakukan aktivitas bisnis mengakibatkan perusahaan perlu menyesuaikan aktivitas bisnisnya dengan perkembangan teknologi yang ada (Thurau et al., 2010).

E-commerce merupakan salah satu dampak dari kemunculan internet yang saat ini dimanfaatkan oleh pelaku bisnis di Indonesia. E-commerce didefinisikan sebagai jual beli online, dimana meliputi transaksi-transaksi bisnis yang dihubungkan melalui internet (Malau, 2017:298). Banyak pengusaha yang mulai mengembangkan ataupun membangun bisnis dengan memanfaatkan e-commerce. Survey yang dilakukan Asosiasi Penyelenggara Jasa Internet Indonesia (APJII) tahun 2016 menyatakan bahwa 63,5\% pengguna internet di Indonesia pernah melakukan transaksi secara online. Hasil survey tersebut menunjukkan bahwa sebagian besar masyarakat Indonesia telah memanfaatkan e-commerce untuk memenuhi kebutuhannya.

Tingginya minat belanja online masyarakat Indonesia, mendorong $e$ commerce tumbuh semakin pesat untuk menyediakan layanan yang diinginkan konsumen. Mengingat kesibukan yang semakin bertambah, menyebabkan 
kurangnya waktu untuk melakukan kegiatan yang dianggap kurang praktis. Adanya keinginan memenuhi segalanya dengan praktis ini berdampak pada perilaku masyarakat, salah satunya dalam pembelian tiket. Survey yang dilakukan Asosiasi Penyelenggara Jasa Internet Indonesia (APJII) tahun 2016 menunjukkan bahwa pembelian tiket meraih persentase tertinggi dalam belanja online yang pernah dilakukan, yaitu sebesar 25,7\%. Hasil survey tersebut menunjukkan antusiasme masyarakat terhadap penggunaan jasa pembelian tiket secara online. Bisnis penyedia tiket perjalanan online merupakan salah satu yang kini terus berkembang di Indonesia. Tersedianya banyak pilihan e-commerce yang menyediakan tiket perjalanan mendorong konsumen untuk membeli tiket perjalanan secara online dibandingkan mendatangi agen perjalanan secara langsung.

Untuk mengetahui jasa penyedia tiket perjalanan online yang sering digunakan oleh masyarakat Kota Denpasar, dilakukan studi pendahuluan dengan wawancara kepada 20 responden.

Tabel 1.

Jasa Online Booking Tiket Pesawat dan Travel yang Sering Digunakan Masyarakat Kota Denpasar

\begin{tabular}{cc}
\hline Merek & Jumlah Responden \\
\hline Traveloka.com & 15 orang \\
Pegipegi.com & 3 orang \\
Trivago.co.id & 2 orang \\
\hline
\end{tabular}

Sumber: Hasil Studi Pendahuluan, 2017

Pada Tabel 1 memperlihatkan hasil dari studi pendahuluan bahwa jasa online booking tiket pesawat dan travel yang paling sering digunakan oleh masyarakat Kota Denpasar adalah Traveloka. Traveloka merupakan perusahaan yang menyediakan situs layanan pemesanan tiket pesawat dan hotel secara online. Pemesanan tiket pesawat memiliki top brand index yang lebih tinggi dibandingkan 
pemesanan hotel pada situs Traveloka pada tahun 2017 (topbrand-award.com). Sistem reservasi tiket yang dimiliki Traveloka, terintegrasi dengan booking sistem dari sejumlah maskapai di Indonesia. Traveloka bekerjasama dengan travel agent resmi maskapai yang sudah terpercaya untuk menerbitkan tiketnya melalui website Traveloka. Hal tersebut memungkinkan konsumen yang akan melakukan pemesanan tiket mendapatkan pilihan yang diinginkan dengan mudah. Laman topbrand-award.com merilis data mengenai popularitas jasa situs online booking tiket pesawat dan travel pada tahun 2016 dan 2017 seperti yang disajikan pada Tabel 2

Tabel 2

Top Brand Award Kategori Online Booking Tiket Pesawat dan Travel (2016-2017)

\begin{tabular}{cccc}
\hline \multicolumn{2}{c}{ Tahun 2016 } & \multicolumn{2}{c}{ Tahun 2017 } \\
Merek & TBI & Merek & TBI \\
\hline Traveloka.com & $74,8 \%$ & Traveloka.com & $78,5 \%$ \\
Tiket.com & $10,3 \%$ & Pegipegi.com & $2,7 \%$ \\
Trivago.co.id & $3,7 \%$ & Tiket.com & $1,6 \%$ \\
Utiket.com & $3,2 \%$ & Wego.co.id & $1,2 \%$ \\
Nusatrip.com & $1,7 \%$ & Nusatrip.com & $1,1 \%$ \\
\hline Sumber: Topbrand-award.com, 2016-2017
\end{tabular}

Kategori online booking tiket pesawat dan travel tahun 2016 hingga 2017 menunjukkan bahwa Traveloka mampu bertahan sebagai pemimpin dalam kategori tersebut. Traveloka memiliki Top Brand Index (TBI) tertinggi selama 2 tahun terakhir di Indonesia, yaitu sebesar 74,8\% pada tahun 2016 dan meningkat menjadi 78,5\% pada tahun 2017. Perolehan tersebut membuktikan bahwa Traveloka merupakan merek yang kuat dibenak pelanggan dan memiliki market share yang tinggi di Indonesia. Kemunculan pesaing baru dengan model bisnis serupa merupakan hal yang perlu diwaspadai oleh Traveloka sebagai pemimpin dalam 
kategori ini. Persaingan yang ketat dalam jasa online booking tiket perjalanan ditunjukkan oleh terus munculnya merek baru yang ikut bersaing pada sektor ini. Semua merek hadir dengan menawarkan kemudahan baru dan kenyamanan bagi konsumennya. Walaupun Traveloka memiliki pencapaian dengan angka yang sangat tinggi, namun beberapa merek yang ikut terjun pada bisnis ini beranggapan bahwa posisi Traveloka masih bisa disaingi (detik.com).

Untuk mampu mempertahankan posisi leader perusahaan tidak hanya memperhatikan kekuatan merek dibenak konsumen dan jumlah pembelian aktual konsumen, melainkan juga perlu memperhatikan bagaimana kekuatan merek dalam mendorong minat konsumen untuk melakukan pembelian kembali di masa depan. Menumbuhkan minat konsumen untuk melakukan pembelian kembali dalam bisnis online tidaklah mudah. Minat beli ulang berkaitan dengan rencana dari konsumen untuk menggunakan kembali merek dalam suatu periode tertentu. Minat konsumen untuk melakukan pembelian kembali menjadi perhatian penting bagi Traveloka. Traveloka harus mengetahui faktor-faktor yang dapat menumbuhkan minat konsumen menggunakan jasa situs online booking Traveloka kembali.

Hasil studi pendahuluan dengan 13 responden pengguna situs Traveloka, diketahui bahwa 8 responden memiliki minat untuk menggunakan kembali jasa Traveloka karena konsumen merasa menggunakan Traveloka lebih mudah dibandingkan dengan situs online booking tiket lainnya. 5 responden lainnya menyatakan karena situs menawarkan produk yang beragam, sehingga memungkinkan konsumen untuk mendapatkan pengalaman yang menyenangkan ketika menggunakan situs Traveloka. Pada konteks belanja online, kemudahan 
penggunaan merupakan elemen yang berpengaruh positif dalam mempengaruhi konsumen melakukan pembelian kembali (Rezaei dan Amin, 2013). Traveloka perlu menyadari bahwa konsumen yang memahami proses pembelian pada situs lebih memiliki niat melakukan pembelian kembali dibandingkan konsumen yang tidak memahami proses pembelian dengan baik. Proses belanja online dengan prosedur yang sederhana akan meningkatkan minat konsumen untuk melakukan pembelian kembali (Adiutama dan Santika, 2014). Kemudahan penggunaan situs perlu diperhatikan untuk tampil lebih baik sebagai strategi dalam persaingan bisnis online (Chong, 2013).

Faktor lain yang dapat mempengaruhi minat konsumen dalam melakukan pembelian kembali adalah perceived enjoyment. Perceived enjoyment adalah motivasi intrinsik yang menekankan pada proses penggunaan dan mencerminkan kesenangan dan kenikmatan yang terkait dengan penggunaan sistem. Pelanggan yang telah merasakan kenikmatan dalam melakukan transaksi online memiliki kecenderungan yang lebih besar untuk melakukan pembelian kembali. Hasil penelitian yang dilakukan oleh Trisnawati dkk. (2012) menunjukkan bahwa perceived enjoyment menjadi prediktor yang konsisten dan kuat terhadap belanja online. Konsumen melakukan pembelian ulang karena bermain-main dengan internet adalah kesenangan tersendiri bagi konsumen. Ada banyak hal yang dapat minat konsumen untuk mengunjungi sebuah situs, salah satunya adalah menciptakan daya tarik situs (Baskara dan Sukaatmadja, 2016). Kesenangan ketika melihat produk-produk yang ditawarkan pada situs, kebebasan membuka situs belanja online serta pilihan produk yang beragam dapat secara signifikan 
mempengaruhi niat konsumen untuk melakukan pembelian kembali (Pramesthi dan Haryanto, 2013).

Hasil yang berbeda ditemukan oleh Oroh (2015) yang menyatakan bahwa perceived ease of use tidak signifikan mempengaruhi niat konsumen melakukan pembelian kembali. Banyaknya konsumen yang merasa penggunaan suatu sistem dan prosedur pembayaran yang rumit merupakan hal yang harus diperhatikan oleh pelaku bisnis online. Begitupula penelitian yang dilakukan oleh Juniwati (2015) yang menyatakan bahwa perceived enjoyment tidak mempengaruhi konsumen dalam melakukan pembelian ulang. Hal tersebut mendukung penelitian yang dilakukan oleh Lin et al. (2010) yang menyatakan bahwa baik perceived ease of use maupun perceived enjoyment tidak memiliki pengaruh langsung yang signifikan terhadap niat membeli kembali, namun memiliki pengaruh tidak langsung melalui kepuasan pelanggan. Hal ini mencerminkan bahwa persepsi konsumen akan meningkatkan minat pembelian ulang apabila mendapatkan kepuasan ketika melakukan belanja online, karena kepuasan yang pada akhirnya akan menentukan minat konsumen melakukan pembelian kembali. Lin dan Lekhawipat (2014) menyebutkan bahwa customer satisfaction berpengaruh positif terhadap repurchase intention. Jika pengguna puas terhadap sistem, maka akan meningkatkan minat melakukan penggunaan ulang, begitupun sebaliknya (Zhou, 2013). Terciptanya kepuasan membentuk persepsi positif dari pelanggan dan kemudian akan mendorong konsumen melakukan pembelian ulang pada merek yang sama (Lu et al., 2013). 
Penelitian mengenai hubungan antara perceived ease of use, customer satisfaction dan repurchase intention pernah dilakukan oleh Chen (2012) yang menyatakan bahwa membentuk persepsi kemudahan penggunaan akan dapat meningkatkan kepuasan konsumen yang akan mendorong minat konsumen melakukan pembelian berulang. Keterkaitan diantara variabel perceived enjoyment, customer satisfaction dan repurchase intention juga diperkuat oleh penelitian yang dilakukan oleh Baskara dan Sukaatmadja (2016) pada Lazada Indonesia yang menyatakan bahwa satisfaction secara signifikan memediasi pengaruh perceived enjoyment terhadap repurchase intention. Beranjak dari penelitian tersebut, penulis tertarik untuk menggabungkan kedua model dan meneliti kembali peran customer satisfaction memediasi pengaruh perceived ease of use dan perceived enjoyment terhadap repurchase intention pada lokasi penelitian yang berbeda yaitu pada penggunaan jasa Traveloka di Kota Denpasar.

Rumusan masalah dalam penelitian ini adalah bagaimana pengaruh perceived ease of use dan perceived enjoyment terhadap customer satisfaction, bagaimana pengaruh perceived ease of use dan perceived enjoyment terhadap repurchase intention serta bagaimana peran customer satisfaction memediasi pengaruh perceived ease of use dan perceived enjoyment terhadap repurchase intention. Penelitian ini bertujuan untuk menjelaskan masing-masing pengaruh perceived ease of use dan perceived enjoyment terhadap repurchase intention serta menjelaskan peran customer satisfaction dalam memediasi pengaruh perceived ease of use dan perceived enjoyment terhadap repurchase intention. Berdasarkan tujuan penelitian, penelitian ini diharapkan dapat memberi manfaat diantaranya 
dapat menambah bukti empiris tentang studi yang membahas hubungan perceived ease of use, perceived enjoyment, customer satisfaction dan repurchase intention dan diharapkan dapat menjadi informasi sebagai bahan pertimbangan pengambilan keputusan bagi Traveloka.

Perceived ease of use didefinisikan sebagai tingkat kepercayaan individu yang menggunakan teknologi baru akan bebas dari usaha yang keras (Davis, 1989). Menurut Wahyuningtyas dan Widiastuti (2015) perceived ease of use (persepsi kemudahan) akan berdampak kepada perilaku, yaitu semakin tinggi persepsi seseorang tentang kemudahan dalam menggunakan sistem, semakin tinggi pula tingkat pemanfaatan teknologi tersebut.

Perceived enjoyment (kenikmatan) adalah salah satu jenis kebutuhan yang berdasarkan arah dari motivasi yang bersifat subjektif dan experiental, yang berarti bahwa konsumen akan mengandalkan suatu produk atau melakukan kegiatan tertentu untuk menemukan kebutuhan mereka sebagai pemberi kegembiraan, kepercayaan diri, khayalan atau tanggapan emosional dan lainnya (Utami, 2010:49). Adanya kenikmatan yang dirasakan dapat menyebabkan para pelanggan akan menyukai bahwa belanja online itu menyenangkan, tetapi jika belanja online itu kurang mendapatkan kenikmatan dari pelanggan, mereka bisa saja berpikir bahwa belanja online tidaklah berguna (Trisnawati dkk., 2012).

Customer satisfaction (kepuasan) adalah perasaan senang atau kecewa seseorang yang timbul karena membandingkan kinerja yang dipersepsikan produk atau hasil terhadap ekspektasi mereka. Jika kinerja gagal memenuhi ekspektasi, pelanggan akan tidak puas. Jika kinerja sesuai dengan ekspektasi, pelanggan akan 
sangat puas atau senang (Kotler dan Keller, 2009:138). Kepuasan konsumen yang tinggi merupakan indikator terbaik dari keuntungan masa depan perusahaan dan secara luas ditandai sebagai evaluasi pasca pembelian (Cengiz, 2010).

Repurchase merupakan kecenderungan perilaku membeli dari konsumen pada suatu produk barang atau jasa yang dilakukan secara berulang dalam jangka waktu tertentu dan secara aktif menyukai dan mempunyai sikap positif terhadap suatu produk barang atau jasa, didasarkan pada pengalaman yang telah dilakukan dimasa lampau (Suryana dan Dasuki, 2013). Repurchase intention timbul setelah konsumen mencoba produk tersebut dan kemudian timbul rasa suka atau tidak suka terhadap produk tersebut (Abdullah, 2003:25). Menurut Nurhayati (2012) repurchase intention adalah keinginan dan tindakan konsumen untuk membeli ulang suatu produk, karena adanya kepuasan yang diterima sesuai yang dinginkan dari suatu produk. Merek yang sudah melekat dalam hati pelanggan akan menyebabkan pelanggan melanjutkan pembelian atau pembelian ulang. Repurchase intention juga dapat digunakan untuk memprediksi apakah konsumen bisa menjadi pelanggan jangka panjang dan membawa keuntungan yang stabil bagi perusahaan atau sebaliknya (Meng et al., 2011).

Amin et al. (2014) mengemukakan bahwa perceived ease of use berpengaruh positif dan signifikan terhadap customer satisfaction. Kemudahan dalam mempelajari dan menggunakan suatu sistem secara positif dapat meningkatkan kepuasan konsumen. Hasil serupa ditemukan oleh penelitian yang dilakukan Hidayat dan Winarno (2014) yang menyatakan bahwa kepuasan konsumen secara positif dan signifikan dipengaruhi oleh kemudahan penggunaan. Penelitian lain 
yang dilakukan Tandon et al. (2016) menemukan hasil serupa bahwa perceived ease of use berpengaruh positif terhadap customer satisfaction. Hal tersebut mengindikasikan bahwa semakin besar kemudahan yang dirasakan saat melakukan pembelian akan meningkatkan kepuasan konsumen dalam berbelanja online. Berdasarkan penelitian-penelitian tersebut maka dapat disusun hipotesis sebagai berikut:

$\mathrm{H}_{1}$ : Perceived ease of use berpengaruh positif dan signifikan terhadap customer satisfaction

Juniwati (2015) mengemukakan bahwa perceived enjoyment berpengaruh positif dan signifikan terhadap customer satisfaction. Kesenangan atau kenikmatan yang dirasakan saat melakukan pembelian memiliki pengaruh yang penting pada perilaku pelanggan. Penelitian yang dilakukan oleh Wen et al. (2011) menyatakan bahwa penampilan website yang menarik merupakan salah satu elemen perceived enjoyment yang akan meningkatkan kepuasan pelanggan secara positif dan signifikan dalam melakukan pembelian. Baskara dan Sukaatmadja (2016) mengungkapkan bahwa kualitas situs serta desain website yang menawarkan berbagai produk serta harga yang beragam dapat menarik konsumen untuk mengunjunginya. Kesenangan atau kenikmatan yang dirasakan pengguna dalam melakukan penjelajahan website secara langsung dapat meningkatkan kepuasan konsumen. (Fang et al., 2016). Berdasarkan penelitian-penelitian tersebut maka dapat disusun hipotesis sebagai berikut:

$\mathrm{H}_{2}$ : Perceived enjoyment berpengaruh positif dan signifikan terhadap customer satisfaction 
Rezaei dan Amin (2013) menyatakan kemudahan dalam penggunaan suatu sistem akan secara positif dan signifikan dapat meningkatkan minat konsumen untuk melakukan pembelian ulang. Penelitian yang dilakukan Juniwati (2015) menunjukkan bahwa sangat penting bagi pemasar untuk memperhatikan kemudahan dalam prosedur pembelian suatu produk. Semakin mudah prosedur pembelian dinilai dapat meningkatkan ketertarikan konsumen untuk melakukan pembelian ulang. Sejalan dengan penelitian yang ada, hasil serupa diungkapkan oleh Chong (2013), Adiutama dan Santika (2014) serta Apriyani dan Suharti (2017) yang menyatakan bahwa perceived ease of use berpengaruh positif dan signifikan terhadap repurchase intention. Berdasarkan penelitian-penelitian tersebut maka dapat disusun hipotesis sebagai berikut:

$\mathrm{H}_{3}$ : Perceived ease of use berpengaruh positif dan signifikan terhadap repurchase intention

Penelitian yang dilakukan oleh Trisnawati dkk. (2012) menyatakan bahwa desain situs yang menarik dan pemberian informasi yang baik saat melakukan belanja online merupakan elemen dari perceived enjoyment yang memiliki pengaruh positif dan signifikan dalam meningkatkan keinginan konsumen melakukan pembelian kembali (repurchase intention). Baskara dan Sukaatmadja (2016) menunjukkan bahwa untuk memperoleh efek yang positif dan signifikan pada minat pembelian kembali, maka perusahaan harus mampu memberikan kenyamanan serta situs yang menarik untuk dikunjungi. Hasil penelitian yang dilakukan Pramesthi dan Haryanto (2013) mengungkapkan bahwa kesenangan yang dirasakan konsumen saat mengunjungi situs belanja online dapat 
mempengaruhi minat konsumen untuk melakukan pembelian kembali. Penelitian yang dilakukan Tambunan dan Handayani (2017) menunjukkan hasil serupa bahwa perceived enjoyment berpengaruh positif dan signifikan terhadap repurchase intention. Berdasarkan penelitian-penelitian tersebut maka dapat disusun hipotesis sebagai berikut:

$\mathrm{H}_{4}$ : Perceived enjoyment berpengaruh positif dan signifikan terhadap repurchase intention

Lin dan Lekhawipat (2014) mengemukakan bahwa customer satisfaction memainkan peranan yang penting dalam mempengaruhi minat pembelian kembali (repurchase intention). Konsumen yang merasa puas cenderung memiliki minat melakukan pembelian kembali dibandingkan dengan konsumen yang tidak puas. Semakin tinggi tingkat kepuasan konsumen maka semakin tinggi pula niat konsumen melakukan pembelian kembali (Zhou, 2013). Penelitian lain yang dilakukan oleh Baskara dan Sukaatmadja (2016) menunjukkan hal serupa yang menunjukkan bahwa satisfaction berpengaruh positif dan signifikan terhadap repurchase intention. Berdasarkan penelitian-penelitian tersebut maka dapat disusun hipotesis sebagai berikut:

$\mathrm{H}_{5}$ : Customer satisfaction berpengaruh positif dan signifikan terhadap repurchase intention

Penelitian yang dilakukan Oroh dkk. (2015) menyatakan bahwa perceived ease of use tidak signifikan terhadap repurchase intention. Penelitian yang dilakukan Lin et al. (2010) menyatakan hal serupa bahwa perceived ease of use tidak memiliki pengaruh langsung yang signifikan terhadap repurchase intention, namun menunjukkan pengaruh tidak langsung melalui customer satisfaction. 
Indikasi ini juga semakin diperkuat oleh penelitian Chen (2012) yang menyatakan bahwa penting bagi perusahaan untuk mampu meningkatkan layanan untuk konsumen salah satunya adalah kemudahaan penggunan sistem. Kemudahan penggunaan dinilai dapat meningkatkan kepuasan konsumen sehingga berniat melakukan pembelian ulang. Berdasarkan penelitian-penelitian tersebut maka dapat disusun hipotesis sebagai berikut:

$\mathrm{H}_{6}$ : Customer satisfaction mampu secara signifikan memediasi perceived ease of use terhadap repurchase intention

Penelitian yang dilakukan oleh Juniwati (2015) mengemukakan bahwa perceived enjoyment tidak mempengaruhi konsumen dalam pembelian ulang. Lin et al. (2010) menunjukkan bahwa perceived enjoyment memiliki pengaruh tidak langsung terhadap repurchase intention dan dalam pengaruhnya sepenuhnya dimediasi oleh customer satisfaction. Hubungan ini diperkuat dengan penelitian yang dilakukan oleh Baskara dan Sukaatmadja (2016) yang menunjukkan bahwa satisfaction berperan secara signifikan memediasi pengaruh perceived enjoyment terhadap repurchase intention. Hal tersebut berarti semakin besar perceived enjoyment yang dirasakan, maka akan semakin tinggi juga kepuasan konsumen, dimana hal tersebut akan mampu meningkatkan minat konsumen untuk melakukan pembelian kembali. Berdasarkan penelitian-penelitian tersebut maka dapat disusun hipotesis sebagai berikut:

$\mathrm{H}_{7}$ : Customer satisfaction mampu memediasi secara signifikan perceived enjoyment terhadap repurchase intention 


\section{METODE PENELITIAN}

Penelitian ini merupakan penelitian yang bersifat asosiatif. Kota Denpasar sebagai lokasi penelitian karena merupakan pusat kota yang tentunya memiliki banyak masyarakat yang sadar akan perkembangan teknologi sehingga memiliki kemampuan untuk menggunakan situs Traveloka. Populasi dalam penelitian ini adalah masyarakat Kota Denpasar yang memiliki pendidikan terakhir minimal SMA dan sudah pernah melakukan pembelian melalui situs Traveloka minimal sekali dalam enam bulan terakhir. Jumlah sampel yang digunakan pada penelitian ini adalah 120 responden.

Teknik pengumpulan data dilakukan dengan penyebaran kuesioner dan diukur menggunakan skala Likert. Sumber data yang digunakan adalah sumber primer yaitu responden dan sumber sekunder seperti hasil survey Asosiasi Penyelenggara Jasa Internet Indonesia (APJII) tahun 2016 serta website top-brand award. Jenis data yang digunakan adalah data kualitatif berupa tanggapan responden atas pernyataan yang diajukan dalam kuesioner serta data kuantitatif berupa usia responden yang mengisi kuesioner. Variabel yang digunakan dalam penelitian ini adalah perceived ease of use dan perceived enjoyment sebagai variabel independen, customer satisfaction sebagai variabel intervening dan repurchase intention sebagai variabel dependen.

Pengukuran dari masing-masing variabel memiliki indikator diantaranya: indikator variabel perceived ease of use adalah fleksibel, mudah dipelajari dan prosedur jelas. Indikator variabel perceived enjoyment adalah kenyamanan bertransaksi, desain menarik dan kesenangan. Indikator variabel customer 
satisfaction adalah kepuasan secara keseluruhan, konfirmasi harapan, pilihan yang tepat. Indikator variabel repurchase intention adalah frekuensi pembelian, komitmen pelanggan dan rekomendasi positif.

Penelitian ini menggunakan teknik analisis jalur (path analysis). Ghozali (2013:249) mendefinisikan analisis jalur sebagai perluasan dari analisis regresi linear berganda dalam memperkirakan hubungan kausalitas antara variabel yang telah ditetapkan sebelumnya berdasarkan teori. Riduwan Kuncoro menyatakan analisis jalur digunakan untuk menganalisis pola hubungan antar variabel dengan tujuan untuk mengetahui pengaruh langsung maupun tidak langsung seperangkat variabel independen terhadap variabel dependen. Langkah-langkah dalam menganalisis data dengan menggunakan path analysis adalah: 1) Merumuskan hipotesis dan persamaan structural, 2) menghitung koefisien jalur yang didasarkan pada koefisien regresi, 3) Menghitung koefisien jalur secara simultan 4) Menghitung koefisien jalur secara individual 5) Meringkas dan menyimpulkan.

Teknik lain yang digunakan pada analisis data adalah uji Sobel. Uji Sobel digunakan untuk menguji kekuatan pengaruh tidak langsung variabel independen terhadap dependen melalui variabel intervening. Apabila nilai kalkulasi Z lebih besar dari 1,96 (dengan tingkat kepercayaan 95 persen) maka variabel mediator dinilai secara signifikan memediasi hubungan antara variabel independen dan dependen.

\section{HASIL DAN PEMBAHASAN}

Responden penelitian ini adalah pengguna Traveloka di Kota Denpasar. Jumlah sampel yang digunakan dalam penelitian ini adalah 120 sampel. Kuesioner 
yang disebarkan adalah sebanyak 125 kuesioner yang disebarkan baik secara online maupun secara langsung. Kuesioner online yang tidak lolos sebagai sampel berjumlah 5 kuesioner karena tidak memenuhi persyaratan pada screening question. Total responden yang digunakan dalam penelitian ini adalah 120 responden sesuai dengan jumlah sampel penelitian dengan karakteristik sebagai berikut:

Karakteristik reponden dalam penelitian ini disajikan pada Tabel 3. sebagai berikut.

Tabel 3.

Karakteristik Responden

\begin{tabular}{|c|c|c|c|c|}
\hline No. & Variabel & Klasifikasi & $\begin{array}{l}\text { Jumlah } \\
\text { (orang) }\end{array}$ & $\begin{array}{c}\text { Persentase } \\
(\%)\end{array}$ \\
\hline \multirow{4}{*}{1} & \multirow{4}{*}{ Usia } & $18-22$ tahun & 90 & 75 \\
\hline & & $23-27$ tahun & 21 & 17.5 \\
\hline & & $28-32$ tahun & 2 & 1.67 \\
\hline & & 33 tahun keatas & 7 & 5.83 \\
\hline \multirow{5}{*}{2} & \multirow{4}{*}{ Jenis kelamin } & \multicolumn{2}{|l|}{ Jumlah } & 100 \\
\hline & & Perempuan & 79 & 65.83 \\
\hline & & Laki - laki & 41 & 34.17 \\
\hline & & \multicolumn{2}{|l|}{ Jumlah } & 100 \\
\hline & \multirow{4}{*}{ Pekerjaan } & Mahasiswa & 77 & 64.16 \\
\hline \multirow{3}{*}{3} & & Karyawan swasta & 26 & 21.67 \\
\hline & & PNS & 9 & 7.5 \\
\hline & & Wiraswasta & 8 & 6.67 \\
\hline \multirow{4}{*}{4} & \multirow{4}{*}{$\begin{array}{l}\text { Pendidikan } \\
\text { Terakhir }\end{array}$} & \multicolumn{2}{|l|}{ Jumlah } & 100 \\
\hline & & SMA & 81 & 67.5 \\
\hline & & Perguruan Tinggi & 39 & 32.5 \\
\hline & & \multicolumn{2}{|l|}{ Jumlah } & 100 \\
\hline
\end{tabular}

Sumber: Data diolah, 2017

Uji pertama yang digunakan adalah uji validitas. Pernyataan dalam kuesioner dikatakan valid jika koefisien korelasi $\geq 0,3$. Hasil pengukuran validitas masing masing intrumen pada variabel disajkan dalam Tabel 4 sebagai berikut. 
Tabel 4

Hasil Uji Validitas

\begin{tabular}{cclcc}
\hline No. & \multicolumn{1}{c}{ Variabel } & \multicolumn{1}{c}{ Indikator } & $\begin{array}{c}\text { Koefisien } \\
\text { Korelasi }\end{array}$ & Ket. \\
\hline \multirow{3}{*}{ 1. } & \multirow{2}{*}{ Perceived Ease of Use } & Fleksibel & 0,892 & Valid \\
& & Mudah dipelajari & 0,874 & Valid \\
& & Prosedur jelas & 0,867 & Valid \\
& & Kenyamanan bertransaksi & 0,872 & Valid \\
2. & \multirow{2}{*}{ Perceived Enjoyment } & Desain menarik & 0,879 & Valid \\
& & Kesenangan & 0,813 & Valid \\
& & Kepuasan secara keseluruhan & 0,876 & Valid \\
3. & Customer Satisfaction & Konfirmasi harapan & 0,918 & Valid \\
& & Pilihan yang tepat & 0,789 & Valid \\
& & Frekuensi pembelian & 0,902 & Valid \\
4. & Repurchase Intention & Komitmen pelanggan & 0,958 & Valid \\
& & Rekomendasi positif & 0,944 & Valid \\
\hline Sumber: Data diolah, 2017 & & &
\end{tabular}

Uji selanjutnya adalah uji reliabilitas. Uji reliabilitas bertujuan untuk mengukur konsitensi alat ukur yang digunakan. Suatu intrumen dapat dikatakan raliabel apabila koefisien alpha cronbach $\geq 0,6$. Hasil pengukuran reliabilitas masing - masing variabel disajikan dalam Tabel 5 sebagai berikut.

Tabel 5.

Hasil Uji Reabilitas

\begin{tabular}{cccc}
\hline No. & Variabel & Cronbach's Alpha & Keterangan \\
\hline 1. & Perceived Ease of Use & 0,848 & Reliabel \\
2. & Perceived Enjoyment & 0,807 & Reliabel \\
3. & Customer Satisfaction & 0,827 & Reliabel \\
4. & Repurchase Intention & 0,922 & Reliabel \\
\hline \multicolumn{2}{l}{ Sumber: }
\end{tabular}

Sumber: Data diolah, 2017

Hasil pada Tabel 5 menunjukkan bahwa masing - masing variabel memiliki koefisien alpha cronbach lebih besar dari 0,3 sehingga dapat disimpulkan bahwa semua indikator yang digunakan merupakan indikator yang konsisten.

Hasil dari pengujian KMO pada masing - masing variabel disajikan dalam Tabel 6 sebagai berikut: 
Tabel 6.

Hasil Uji KMO Variabel Penelitian

\begin{tabular}{lll}
\hline No. & \multicolumn{1}{c}{ Variabel } & KMO \\
\hline 1. & Perceived Ease of Use & 0,722 \\
2. & Perceived Enjoyment & 0,718 \\
3. & Customer Satisfaction & 0,721 \\
4. & Repurchase Intention & 0,721 \\
\hline \multicolumn{2}{l}{ Sumber: Data diolah, 2017 }
\end{tabular}

Hasil pada Tabel 6 menunjukkan nilai KMO semua variabel lebih besar 0,5 sehingga dapat disimpulkan bahwa semua variabel dapat diproses lebih lanjut.

Hasil dari pengujian MSA pada masing - masing variabel disajikan dalam Tabel 7 sebagai berikut.

\section{Tabel 7 \\ Hasil Uji MSA}

\begin{tabular}{cccc}
\hline No. & Variabel & Indikator & Nilai MSA \\
\hline \multirow{2}{*}{ 1. } & Perceived Ease of Use & $\mathrm{X}_{1.1}$ & 0,678 \\
& $\left(\mathrm{X}_{1}\right)$ & $\mathrm{X}_{1.2}$ & 0,791 \\
& & $\mathrm{X}_{1.3}$ & 0,716 \\
2. & $\mathrm{X}_{2.1}$ & 0,772 \\
& Perceived Enjoyment $\left(\mathrm{X}_{2}\right)$ & $\mathrm{X}_{2.2}$ & 0,702 \\
& & $\mathrm{X}_{2.3}$ & 0,691 \\
3. & $\mathrm{Y}_{1.1}$ & 0,759 \\
& & $\mathrm{Y}_{1.2}$ & 0,701 \\
& & $\mathrm{Y}_{1.3}$ & 0,709 \\
4. & Repurchase Intention $\left(\mathrm{Y}_{2}\right)$ & $\mathrm{Y}_{2.1}$ & 0,750 \\
& & $\mathrm{Y}_{2.2}$ & 0,767 \\
& & $\mathrm{Y}_{2.3}$ & 0,663 \\
\hline
\end{tabular}

Sumber: Data diolah, 2017

Dari hasil pengukuran MSA, diperoleh hasil masing-masing variabel memiliki nilai lebih besar dari pada 0,5 sehingga kelima variabel tersebut telah memenuhi syarat untuk analisis faktor.

Hasil pengujian Percentage of variance masing - masing variabel disajikan dalam Tabel 8 sebagai berikut. 
Tabel 8

Hasil Uji Precentage of Variance

\begin{tabular}{cccc}
\hline No. & & Variabel & Precentage of Variance \\
\hline 1. & $\mathrm{X}_{1}$ & Perceived Ease of Use & 78,989 \\
2. & $\mathrm{X}_{2}$ & Perceived Enjoyment & 75,314 \\
3. & $\mathrm{Y}_{1}$ & Customer Satisfaction & 75,087 \\
4. & $\mathrm{Y}_{2}$ & Repurchase Intention & 82,183 \\
\hline \multicolumn{2}{l}{ Sumber: } & Data diolah, 2017
\end{tabular}

Dari hasil pengukuran percentage of variance, nilai dari masing - masing variabel lebih besar dari $60 \%$, sehingga dapat disimpulkan bahwa kombinasi faktor yang disusun sudah dapat digunakan.

Hasil pengujian loading factor masing - masing variabel disajikan dalam Tabel 9 sebagai berikut.

Tabel 9
Nilai Loading Factor

\begin{tabular}{cccc}
\hline No. & Variabel & Instrumen & $\begin{array}{c}\text { Nilai } \\
\text { Loading } \\
\text { Factor }\end{array}$ \\
\hline \multirow{2}{*}{ 1. } & Perceived Ease of Use $\left(\mathrm{X}_{1}\right)$ & $\mathrm{X}_{1.1}$ & 0,914 \\
& & $\mathrm{X}_{1.2}$ & 0,860 \\
& $\mathrm{X}_{1.3}$ & 0,892 \\
2. $\quad$ Perceived Enjoyment $\left(\mathrm{X}_{2}\right)$ & $\mathrm{X}_{2.1}$ & 0,842 \\
& & $\mathrm{X}_{2.2}$ & 0,877 \\
3. $\quad$ Customer Satisfaction $\left(\mathrm{Y}_{1}\right)$ & $\mathrm{X}_{2.3}$ & 0,884 \\
& & $\mathrm{Y}_{1.1}$ & 0,848 \\
& & $\mathrm{Y}_{1.2}$ & 0,878 \\
4. & $\mathrm{Y}_{1.3}$ & 0,873 \\
& & $\mathrm{Y}_{2.1}$ & 0,894 \\
& & $\mathrm{Y}_{2.2}$ & 0,888 \\
& & $\mathrm{Y}_{2.3}$ & 0,936 \\
\hline
\end{tabular}

Sumber: Data diolah, 2017

Dari hasil pengukuran loading factor, nilai dari masing - masing instrumen lebih besar dari 0,5 sehingga dapat disimpulkan seluruh indikator yang digunakan telah memenuhi syarat menjadi indikator konstruk perceived ease of use, perceived enjoyment, customer satisfaction dan repurchase intention. 
Perhitungan pengaruh antar variabel untuk membuktikan hipotesis dirangkum dalam Tabel 10 sebagai berikut:

Tabel 10

Pengaruh Langsung, Pengaruh Tidak Langsung serta Pengaruh Total

\begin{tabular}{ccccc}
\hline No. & $\begin{array}{c}\text { Pengaruh } \\
\text { Variabel }\end{array}$ & $\begin{array}{c}\text { Pengaruh } \\
\text { Langsung }\end{array}$ & $\begin{array}{c}\text { Pengaruh Tidak Langsung } \\
\text { Melalui Customer Satisfaction }\end{array}$ & Pengaruh Total \\
\hline 1. & $X 1 \rightarrow Y 1$ & 0,404 & - & 0,404 \\
2. & $X 2 \rightarrow Y 1$ & 0,518 & - & 0,518 \\
3. & $X 1 \rightarrow Y 2$ & 0,364 & 0,129 & 0,493 \\
4. & $X 2 \rightarrow Y 2$ & 0,257 & 0,165 & 0,422 \\
5. & $Y 1 \rightarrow Y 2$ & 0,320 & - & 0,320 \\
\hline \multicolumn{5}{l}{ Sumber: Data diolah, 2017}
\end{tabular}

Uji terakhir yang dilakukan adalah uji Sobel. Berdasarkan perhitungan yang telah dilakukan, diperoleh nilai Z sebesar 2,4562 > 1,96 ini berarti variabel mediasi yaitu variabel customer satisfaction secara signifikan memediasi perceived ease of use terhadap repurchase intention. Berdasarkan perhitungan yang telah dilakukan diperoleh nilai Z sebesar 2,6192 > 1,96 ini berarti variabel mediasi yakni customer satisfaction dinilai secara signifikan memediasi perceived enjoyment terhadap repurchase intention.

Pengujian hipotesis pertama menunjukkan hasil yang diterima dengan koefisien Beta positif sebesar 0,404 dengan tingkat signifikansi 0,000 (kurang dari 0,05). Hasil tersebut berarti variabel perceived ease of use berpengaruh positif dan signifikan terhadap variabel customer satisfaction. Hal tersebut membuktikan bahwa semakin tinggi persepsi kemudahan (perceived ease of use) yang dirasakan maka akan semakin tinggi kepuasan konsumen (customer satisfaction) pada penggunaan situs Traveloka. Hasil penelitian ini mendukung temuan dari penelitian terdahulu yang dilakukan oleh Amin et al. (2014), Hidayat dan Winarno (2014) 
serta Tandon et al. (2016) yang menunjukan bahwa perceived ease of use berpengaruh positif signifikan terhadap customer satisfaction.

Pengujian hipotesis kedua ini menunjukkan hasil yang diterima dengan koefisien Beta positif sebesar 0,518 dengan tingkat signifikansi 0,000 (kurang dari 0,05). Hasil tersebut berarti bahwa variabel perceived enjoyment berpengaruh positif dan signifikan terhadap variabel customer satisfaction. Hal tersebut membuktikan bahwa semakin baik persepsi kenikmatan (perceived enjoyment) yang dirasakan maka akan semakin tinggi kepuasan konsumen (customer satisfaction) pada penggunaan situs Traveloka. Hasil penelitian ini mendukung temuan dari penelitian terdahulu yang dilakukan oleh Juniwati (2015), Wen et al. (2011), Baskara dan Sukaatmadja (2016) serta Fang et al. (2016) yang menunjukan bahwa perceived enjoyment berpengaruh positif signifikan terhadap customer satisfaction.

Pengujian hipotesis ketiga ini menunjukkan hasil yang diterima dengan koefisien Beta positif sebesar 0,364 dengan tingkat signifikansi 0,000 (kurang dari 0,05). Hal tersebut berarti variabel perceived ease of use berpengaruh positif dan signifikan terhadap variabel repurchase intention. Hal tersebut membuktikan bahwa semakin baik persepsi kemudahan (perceived ease of use) yang dirasakan maka akan semakin tinggi minat pembelian ulang (repurchase intention) menggunakan situs Traveloka. Hasil penelitian ini mendukung temuan dari penelitian terdahulu yang dilakukan oleh Rezaei dan Amin (2013), Juniwati (2015), Chong (2013), Adiutama dan Santika (2014) serta Apriyani dan Suharti (2017) 
yang menunjukan bahwa perceived ease of use berpengaruh positif signifikan terhadap repurchase intention.

Pengujian hipotesis keempat ini menunjukkan hasil yang diterima dengan koefisien Beta positif sebesar 0,257 dengan tingkat signifikansi 0,003 (kurang dari 0,05). Hal tersebut berarti variabel perceived enjoyment berpengaruh positif dan signifikan terhadap variabel repurchase intention. Hal tersebut membuktikan bahwa semakin baik persepsi kenikmatan (perceived enjoyment) yang dirasakan maka akan semakin tinggi minat pembelian ulang (repurchase intention) menggunakan situs Traveloka. Hasil penelitian ini mendukung temuan dari penelitian terdahulu yang dilakukan oleh Trisnawati dkk. (2012), Baskara dan Sukaatmadja (2016), Pramesthi dan Haryanto (2013) serta Tambunan dan Handayani (2017) yang menunjukan bahwa perceived enjoyment berpengaruh positif signifikan terhadap repurchase intention.

Pengujian hipotesis kelima ini menunjukkan hasil yang diterima dengan koefisien Beta positif sebesar 0,320 dengan tingkat signifikansi 0,001 (kurang dari 0,05). Hal tersebut berarti variabel customer satisfaction berpengaruh positif dan signifikan terhadap variabel repurchase intention. Hal tersebut membuktikan bahwa semakin baik kepuasan konsumen (customer satisfaction) pada situs maka akan semakin tinggi minat pembelian ulang (repurchase intention) menggunakan situs Traveloka. Hasil penelitian ini mendukung temuan dari penelitian terdahulu yang dilakukan oleh Lin dan Lekhawipat (2014), Zhou (2013) serta Baskara dan Sukaatmadja (2016) menunjukan bahwa customer satisfaction berpengaruh positif signifikan terhadap repurchase intention. 
Made Ayu Swari Oktarini, Pengaruh Perceived Ease of Use dan....

Berdasarkan hasil penelitian, hipotesis yang disusun penulis mengenai peran customer satisfaction dalam memediasi pengaruh perceived ease of use terhadap repurchase intention diterima dengan nilai pengaruh total yang memiliki nilai 0,129 dan dapat dinyatakan sebagai mediasi parsial. Hasil ini juga diperkuat dengan hasil Uji Sobel terhadap nilai $\mathrm{Z}$ dari penelitian yang memperoleh nilai 2,4562 > 1,96 yang berarti bahwa customer satisfaction dinilai mampu memediasi pengaruh perceived ease of use terhadap repurchase intention dengan tingkat keyakinan yang melebihi 95 persen. Hasil penelitian ini mendukung temuan dari penelitian terdahulu yang dilakukan oleh Lin et al. (2010) dan Chen (2012) yang menunjukan bahwa customer satisfaction mampu secara signifikan memediasi perceived ease of use terhadap repurchase intention.

Berdasarkan hasil penelitian, hipotesis yang disusun penulis mengenai peran customer satisfaction dalam memediasi pengaruh perceived enjoyment terhadap repurchase intention diterima dengan nilai pengaruh total yang memiliki nilai 0,166 dan dapat dinyatakan sebagai mediasi parsial. Hasil ini juga diperkuat dengan hasil Uji Sobel terhadap nilai Z dari penelitian yang memperoleh nilai 2,6192 > 1,96 yang berarti bahwa customer satisfaction dinilai mampu memediasi pengaruh perceived enjoyment terhadap repurchase intention dengan tingkat keyakinan yang melebihi 95 persen. Hasil penelitian ini mendukung temuan dari penelitian terdahulu yang dilakukan oleh Lin et al. (2012) serta Baskara dan Sukaatmadja (2016) yang menunjukan bahwa customer satisfaction mampu secara signifikan memediasi perceived enjoyment terhadap repurchase intention. 


\section{SIMPULAN DAN SARAN}

Berdasarkan hasil pembahasan dapat ditarik simpulan bahwa perceived ease of use berpengaruh positif dan signifikan terhadap customer satisfaction, dengan demikian semakin baik perceived ease of use pada penggunaan situs Traveloka, maka customer satisfaction akan semakin meningkat. Perceived enjoyment berpengaruh positif dan signifikan terhadap customer satisfaction. Perceived ease of use berpengaruh positif dan signifikan terhadap repurchase intention. Perceived enjoyment berpengaruh positif dan signifikan terhadap repurchase intention, dengan demikian semakin baik perceived enjoyment pada penggunaan situs Traveloka, maka repurchase intention terhadap situs ini pun semakin meningkat. Customer satisfaction berpengaruh positif dan signifikan terhadap repurchase intention, dengan demikian semakin tinggi customer satisfaction pada penggunaan situs Traveloka, maka repurchase intention terhadap situs ini pun semakin meningkat.

Customer satisfaction mampu memediasi perceived ease of use dengan repurchase intention secara positif dan signifikan, dengan demikian adanya customer satisfaction dalam memediasi dapat meningkatkan pengaruh perceived ease of use terhadap repurchase intention penggunaan situs Traveloka. Customer satisfaction mampu memediasi perceived enjoyment dengan repurchase intention secara positif dan signifikan, dengan demikian adanya customer satisfaction dalam memediasi dapat meningkatkan pengaruh perceived enjoyment terhadap repurchase intention penggunaan situs Traveloka. 
Saran yang dapat diberikan adalah Perusahaan perlu memperhatikan kembali prosedur yang telah dijelaskan pada situs. Pembaruan fitur yang terus dikembangkan oleh perusahaan harus diimbangi dengan diterbitkannya prosedur penggunaannya, sehingga akan mempermudah konsumen dalam penggunaan situs Traveloka. Saat ini Traveloka hanya menyediakan prosedur untuk melakukan pemesanan dan pembayaran pada halaman utama, akan lebih baik bagi perusahaan untuk menyediakan prosedur untuk fitur terbaru yang dirilis salah satunya adalah sistem refund booking, penggunaan e-ticketing dan fitur lainnya yang disediakan oleh perusahaan.

Perusahaan perlu menciptakan desain situs yang menarik sehingga konsumen akan tertarik untuk kembali mengunjungi situs. Perusahaan dapat mendesain situs dengan menambahkan seluruh promo yang diberikan oleh perusahaan pada halaman utama situs, sehingga konsumen akan merasa senang ketika melakukan pembelian dengan situs Traveloka.

Perusahaan perlu memperhatikan kembali kinerja dari situs, sehingga harapan konsumen terhadap e-commerce akan terpenuhi saat menggunakan situs Traveloka. Perkembangan e-commerce yang semakin canggih harus mampu diimbangi oleh perusahaan sehingga kinerja situs akan semakin baik. Sistem feedback dapat diterapkan bagi para konsumen, sehingga perusahaan mengetahui kinerja dari situs tersebut.

Perusahaan perlu memperhatikan kembali persaingan antara bisnis serupa dengan Traveloka, mengingat banyaknya perusahaan serupa yang menawarkan keunggulan baru pada bisnisnya sehingga memungkinkan konsumen untuk beralih 
menggunakan situs lainnya. Perusahaan harus mampu mempertahankan komitmen konsumen untuk tetap menggunakan situs Traveloka dibandingkan situs lainnya.

\section{IMPLIKASI HASIL PENELITIAN DAN KETERBATASAN PENELITIAN}

Implikasi pada hasil penelitian ini menekankan pada manfaat nyata dari hasil penelitian untuk memberikan referensi tambahan dalam menetapkan peran customer satisfaction memediasi perceived ease of use dan perceived enjoyment dengan repurchase intention pada situs Traveloka.

Pertama, terbukti bahwa responden merasakan perceived ease of use yang baik terkait pada pernyataan responden tentang kemudahan penggunaan situs Traveloka. Hal tersebut dibuktikan oleh perolehan skor rata-rata variabel perceived ease of use merupakan skor tertinggi dibandingkan variabel lainnya. Ini berarti konsumen memiliki persepsi yang positif terhadap kemudahan penggunaan situs Traveloka, sehingga strategi Traveloka untuk menciptakan kemudahan bagi konsumennya dapat dikatakan berhasil.

Kedua, konsumen juga memberikan respon yang positif untuk pernyataan pada variabel perceived enjoyment. Konsumen merasa nyaman melakukan transaksi menggunakan situs Traveloka mendapatkan perolehan tertinggi dibandingkan pernyataan lainnya. Hal tersebut membuktikan Traveloka telah berhasil menciptakan kenyamanan bagi konsumennya. Maka sangat penting bagi Traveloka untuk menjaga keamanan transaksi pada situsnya, sehingga konsumen akan tetap merasa nyaman bertransaksi menggunakan situs Traveloka. 
Ketiga, responden memiliki respon yang baik pada pernyataan yang terkait dengan customer satisfaction. Konsumen telah membuat pilihan yang tepat dalam menggunakan situs Traveloka memperoleh skor tertinggi dibandingkan pernyataan lainnya. Hal ini membuktikan bahwa Traveloka berhasil menciptakan kepuasan kepada konsumennya.

Keempat, perlu digarisbawahi bahwa konsumen akan lebih sering menggunakan Traveloka untuk keperluan perjalanan, memperoleh skor tertinggi dibandingkan pernyataan lainnya pada variabel repurchase intention. Hal tersebut membuktikan bahwa Traveloka telah berhasil menciptakan minat konsumen untuk melakukan pembelian kembali pada situs Traveloka. Atas hasil dan temuan tersebut, penulis menyarankan agar dapat memuaskan konsumen - konsumennya dengan menciptakan persepsi positif dan lebih lanjut dapat menimbulkan minat konsumen untuk melakukan pembelian kembali menggunakan situs Traveloka.

Keterbatasan dalam penelitian ini adalah ruang lingkup penelitian yang hanya dilakukan di Kota Denpasar, sehingga hasil dari penelitian ini tidak dapat digeneralisasi untuk konsumen yang berada di daerah lainnya serta masih terdapat faktor lain yang dapat mempengaruhi repurchase intention, namun karena keterbatasan waktu, biaya dan tenaga penelitian ini hanya melibatkan variabel perceived ease of use dan perceived enjoyment. 


\section{REFERENSI}

Abdullah, Thamrin. 2003. Manajemen Pemasaran. Jakarta: PT. Rajawali Pers.

Adiutama, I Made Rendy Wicaksana dan I Wayan Santika. 2014. Pengaruh Persepsi Kemudahan Penggunaaan, Kegunaan yang dirasakan, dan tingkat pendidikan terhadap niat berbelanja kembali pada situs tokobagus.com. $E$ Jurnal Manajemen Unud, 3 (10):2815-2831.

Amin, Muslim. Sajad Rezei and Maryam Abolghasemi. 2014. User satisfaction with mobile websites: the impact of perceived usefulness (PU), perceived ease of use (PEOU) and trust. Nankai Business Review International, 5 (3):258-274.

Apriyani, Nuri dan Suharti. 2017. Analisis Pengaruh Persepsi Kebermanfaatan, Persepsi Kemudahan dan Kepercayaan Terhadap Minat Beli Ulang Pengguna Smartphone Xiaomi. Jurnal Manajemen Dewantara, 1 (1):21-34.

Asosiasi Penyelenggara Jasa Internet Indonesia (APJII). 2016. Penetrasi \& Perilaku Pengguna Internet Indonesia Survey 2016. Jakarta: APJII.

Baskara, I Made Arya dan I Putu Gde Sukaatmadja. 2016. Pengaruh Online Trust dan Perceived Enjoyment Terhadap Online Shopping Satisfaction dan Repurchase Intention Lazada Indonesia. E-Jurnal Manajemen Unud, 5 (11):7214-7244.

Cengiz, Emrah. 2010. Measuring Customer Satisfaction: must or not?. Journal of Naval Science and Enginering, 6(2):76-88.

Chen, Yue-Yang. 2012. Why Do Consumers Go Internet Shopping Again? Understanding the Antecedents of Repurchase Intention. Journal of Organizational Computing and Electronic Commerce, 22 (1):38-63.

Chong, A.Y.L. 2013. Understanding mobile commerce continuance intention: An empirical analysis of Chinese consumers. The Journal of Computer Information Systems, 53(4):22-30.

Davis, F. D. 1989. Perceived Usefulness, Perceived Ease of Use, and User Acceptance of Information Technology, MIS Quarterly, 13(3):319-340.

Fang, Jiaming, Yunfei Shao and Chao Wen. 2016. Transactional quality, relational quality, and consumer e-loyalty: Evidence from SEM and fsQCA. International Journal of Information Management, 36 (6):1205-1217.

Ghozali, Imam. 2013. Aplikasi Analisis Multivariate dengan Program IBM SPSS 2.1, Edisi. Ketujuh, Semarang: Badan Penerbit UNDIP. 
Haryanto, Agus Tri. 2017. Akuisisi Tiket.com, Blibli: Biar Traveloka Tidak Kesepian www.detik.com (diunduh tanggal 20 Juni 2017)

Hidayat, Maulana dan Wing Wahyu Winarno. 2014. Evaluasi Kepuasan Pengguna Wi-fi Dengan Metode Importance-Performance Analysis dan Customer Satisfaction Index (Studi Kasus UGM-Hotspot, Fakultas Teknik, Universitas Gadjah Mada). Tesis Fakultas Teknik Universitas Gadjah Mada.

Juniwati. 2015. Pengaruh Ease of Use, Enjoyment dan Trust terhadap Repurchase Intention dengan Customer Satisfaction Sebagai Variabel Intervening pada Belanja Online (Studi pada Mahasiswa Universitas Tanjungpura Pontianak). Jurnal Ekonomi Bisnis dan Kewirausahaan, 4 (1):140-156.

Kotler, Philip dan Gary Amstrong. 2001. Prinsip-Prinsip Pemasaran. Jakarta: Erlangga.

Kotler, Philip dan Kevin Lane Keller. 2009. Manajemen Pemasaran. Jakarta: Erlangga.

Lin, Chwen-Yea., Kwoting Fang and Chien-Chung Tu. 2010. Predicting Consumer Repurchase Intentions to Shop Online. Journal of Computers, 5(10):15271533.

Lin, Chinho and Watcharee Lekhawipat. 2014. Factors affecting online repurchase intention. Industrial Management \& Data Systems, 114 (4):597-611.

Lu, L.C., Chang H.H and Yu S.T. 2013. Online Shoppers Perceptions of E-retailers Ethics, Cultural Orientation and Loyalty An Exploratory Study in Taiwan. Internet Research, 23 (1):47-68.

Meng, S.M., Gin S.L. and Shih H.Y. 2011. The Relationship of Cruise Image, Perceived Value, Satisfaction and Post-Purchase Behavioral Intention on Taiwanese Tourist. African Journal of Business Management, 5(1):19-29.

Nurhayati dan Wahyu Wijaya Murti. 2012. Analisis Faktor-Saktor Yang Mempengaruhi Minat Beli Ulang Masyarakat Terhadap Produk Handphone. Value Added, 8 (2):47-62.

Nurlinda, R.A. 2013. Pengaruh Customer Satisfaction Strategy Terhadap Peningkatan Kepuasan Konsumen. Forum Ilmiah, 10(2):172-181.

Oroh, Cindy Regina., David P.E.S. dan Farlane S.R. 2015. The Influence of Perceived Ease of Use, Perceived Usefulness and Trust on Repurchase Intention of Lion Air E-Ticket. Jurnal Berkala Ilmiah Efisiensi, 15(5):367376

Parastanti, G.P., Srikandi, K. dan Kadarisman, H. 2014. Pengaruh Prior Online Purchase Experience Terhadap Trust dan Online Repurchase Intention. Jurnal Administrasi Bisnis (JAB), 16 (1):1-7. 
Pramesthi, Febriana dan Haryanto. 2013. Efek Perceived Ease of Use dan Confirmation Terhadap Anteseden Online Repurchase Intention. Fokus Manajerial, 12 (1):81-91.

Puspitasari, Diana. 2006. Analisis Pengaruh Persepsi Kualitas dan Kepuasan Pelanggan Terhadap Minat Beli Ulang. Tesis Universitas Diponegoro.

Riduwan dan Engkos Achmad Kuncoro. 2011. Cara Menggunakan dan Memaknai Analisis Jalur (Path Analysis). Bandung: Alfabeta.

Rezaei, S and Amin, M. 2013. Exploring Online Repurchase Behavioural Intention of University Students in Malaysia. Journal for Global Business Advancement, 6 (2):92-119.

Sugiyono. 2014. Metode Penelitian Bisnis (Pendekatan Kuantitatif, Kualitatif, dan $R \& D)$. Bandung: Alfabeta.

Suharso. 2010. Model Analisis Kuantitatif “TEV”. Jakarta: Indeks.

Suryana, Popo dan Eliyandi S. D. 2013. Analisis Faktor Yang Mempengaruhi Keputusan Pembelian dan Implikasinya Pada Minat Beli Ulang. Trikonomika, 12 (2):190-200.

Tambunan, Samuel dan Wiwik Handayani. 2017. Minat Beli Ulang Kartu Perdana Nomor Cantik Simpati (Studi Dicomtech Shop Surabaya). Manajemen Bisnis, 1 (1):85-92.

Tandon, Urvashi, Ravi Kiran and Ash N.S. 2016. Analysing the Complexities of Website Functionality, Perceived Ease of Use and Perceived Usefullness on Customer Satisfaction of Online Shoppers in India. International Journal of Electronic Marketing and Retailing, 7 (2):115-140

Thurau, T.H., Edward C. Malthouse, Christian F., Sonja G., Lara L., Arvind R. and Bernd S. 2010. The Impact of New Media on Customer Relationships. Journal of Service Research, 13 (3):311-330.

Top Brand Award. 2017. Top Brand Kategori Situs Online Booking Tiket Pesawat dan Travel. www.topbrand-award.com (diunduh tanggal 20 Mei 2017)

Top Brand Award. 2017. Top Brand Criteria. www.topbrand-award.com (diunduh pada 20 Mei 2017)

Trisnawati, Ella, Agus Suroso dan Untung Kumorohadi. 2012. Analisis dari faktorfaktor kunci niat pembelian kembali secara online (Studi Kasus pada Konsumen Fesh Shop). Jurnal Bisnis dan Ekonomi (JBE), 19 (2):126-141.

Utama, S.M. 2010. Aplikasi Analisis Kuantitatif Edisi Ketiga. Denpasar: Sastra Utama.

Utami, Christina Whidya. 2010. Manajemen Ritel (Strategi dan Implementasi Operasional Bisnis Ritel Modern di Indonesia). Jakarta: Salemba Empat. 
Wahyuningtyas, Yunita Fitri dan Dyah Ayu Widiastuti. 2015. Analisis Pengaruh Persepsi Risiko, Kemudahan dan Manfaat Terhadap Keputusan Pembelian Secara Online (Studi Kasus Pada Konsumen Barang Fashion di Facebook). Jurnal Kajian Bisnis, 23 (2):112-120.

Wen, C., Victor, R.P and Chenyan, X. 2011. An Integrated Model for Costumer Online Repurchase Intention. Journal of Computer Information Systems, 52 (1):14-23.

Zhou, Tao. 2013. An Empirical Examination of Continuance Intention of Mobile Payment Services. Decision Support System, 54 (2):1085-1091. 